\title{
PGMI CURRICULUM DESIGN AND STRENGTHENING TEACHER COMPETENCE 21ST CENTURY
}

\author{
Fauzan $^{1}$, Fatkhul Arifin ${ }^{2}$ \\ \{fauzan@uinjkt.ac.id ${ }^{1}$, fatkhul_arf@uinjkt.ac.id $\left.{ }^{2}\right\}$
}

UIN Syarif Hidayatullah Jakarta, Indonesia ${ }^{1,2}$

\begin{abstract}
The purpose of this research is to find out how the curriculum design used by the PGMI Study Program in general and in particular the PGMI Study Program at UIN Jakarta, also, researchers want to know the curriculum design that is used as an effect on or not the competence of graduates. The method used in this study is a descriptive theoretical method, researchers take several sources of theory and relate it to everyday observations. So it can be concluded that the curriculum design used in the UIN Jakarta PGMI Study Program and in general must follow the Indonesian National Curriculum Framework (KKNI). And the competencies that must be possessed by 21 st-century teachers are technological prowess, mastery of soft skills and hard skills.
\end{abstract}

Keywords: 21st Century Teachers, PGMI Curriculum Design, hard skills, and soft skills

\section{Introduction}

The development of 21st-century education is marked by the use of information and communication technology in all lives, including in the world of learning. Nowadays the progress of information technology has many positive impacts on the progress of the world of education. Especially computer and internet technology, both in terms of hardware and software, provides many offers and choices for the world of education to support the learning process. The advantages offered are not only the speed factor to get information but also multimedia facilities that can make learning more interesting, visual and interactive. In line with the development of internet technology, many learning activities can be carried out by utilizing this technology [1].

Many teachers have not made good use of technological developments. Though researchers see the advantages of using technology in learning. They see that learning with technology can build problem-solving skills and provide ample room for students to gather information from various disciplines [2]. Although the use of technology in Indonesia is still lagging behind other countries, in Indonesia it has already used technology in learning [3]

The application of technology in the learning process in schools has slowly begun to be applied in Indonesia. In line with the continued development of technology and advancing technology advances into the interior, despite its limitations, learning can now be done through computers that are accessed to the internet. Learning like this is also called web-based learning (web-based learning), internet learning, or also known as the term e-learning [4]. An e-learning system is a form of learning implementation utilizing the internet through the form of websites and weblogs with multimedia content which is the process of transformation and digitalization of conventional learning. 


\section{21st Century Teacher Profile}

21 st Century society is an open society. Communication between humans in various areas of life will be free from obstacles. Life in the 21 st century demands superior human beings who can survive in a life that is full of competition and demands quality of life, both in products and in the service of shared life. There are two types of superior human beings in the 21st century, namely individualistic excellence and participatory excellence [5]. Individualistic excellence is usually only for its own sake and has no implications for the wider community. Human life in the modern age is directed at the creation of a civil society, which is a society that recognizes the rights and obligations of each member and is jointly responsible for humanity, all humanity building a civil society, peace, and justice into values the highest score. Excellence needed in the 21 st century is participatory excellence, a model of excellence directed towards the common interests of others. In developing superior human participant, it is necessary to develop the following characteristics: 1) the ability to develop cooperation networks, 2) teamwork, and 3) are closely related to the principle of cooperation by upholding high-quality values [6].

To arrive at these needs, superior human beings must, of course, be supported by a value that is firmly embedded in themselves, concerning patterns of relationship with God (spiritual), society and the environment (social). These values include discipline, honesty, responsibility, innovative-creative, hard work, persevering, and resilient. Positive behavior in daily life must be formed through a process of habituation (habituation) continuously and supported by all parties, parents, families, the school environment, teachers, principals, and surrounding communities. This is because the issue of character value formation is a joint issue, not a person to a personal matter. Character values or morals (in Islam) are no longer just the business of "PAI teachers" or Civics teachers, but all teaching professions have the same responsibility in shaping student character values. As habituation, of course, the formation of character values is not in the teaching area (knowledge transfer), but rather the effort or process of learning activities that can have a positive impact or provide meaningful (meaningful) for students. For UNESCO itself there are four pillars of education that can be fulfilled to deal with 21st-century learning, namely learning to know, learning to do, learning to be, learning to live together). The concept of learning is not only for the intellectual intelligence process but the process that directs the personalities of students can work together in a broader framework.

The consequences that can arise from the demand for progress requires the existence of models and learning strategies that can accompany the life of 21 st-century society. For HAR Tilaar (1998) there are three characteristics that become the distinction of 21 st century society, namely (1) technological society, namely the community that can utilize technology as the basis of life interaction, including learning activities; (2) open society, a community that has a wide network and access to life activities; and (3) civil society, a civil society that is civilized, independent and democratic, capable of upholding the values, norms, laws that apply with a common purpose and culture and does not cause acts of abuse of authority [7].

\section{PGMI Study Program Dilemma: Between the Domination of Religion and Science}

The existence of the curriculum in higher education is very central, for several reasons as follows: 1) The source of higher education management policies to determine the direction of 
the implementation of education; (2) Philosophy that will color the formation of society and the academic climate; (3) Patron or learning patterns, which reflect study material, ways of delivering and evaluating learning; (4) The atmosphere or climate formed by the results of PT managerial interaction in achieving its learning goals; (5) Quality references from the quality assurance process; and (6) a measure of the success of the university in producing graduates that are beneficial to society. From this explanation, it appears that the curriculum is not only meant as a document but is a series of very crucial processes in education [8]. The position of the curriculum becomes so important and strategic in the context of improving the quality of higher education. Efforts to improve, change, develop a curriculum based on the needs of the wider community, the development of science and technology is a must.

In the context of the MI Teacher Education Study Program, curriculum design has undergone several changes. First, 2011 was referred to as the year of "reshuffle", reduction, and even merging (merging) of courses because they were considered to be duplicating or colliding with one another. The findings made by the Melbourne Australia Team explained that the PGMI curriculum was classified as still "dense of subjects", even the existence of courses taught was still duplicated between one subject and another. The direction of curriculum development is also unclear between the preparation of "religious experts" (religious teachers) or "classroom teachers" as they were originally established. Public insecurity and the support of government policies (Ministry of Religion and Ministry of Education and Culture) which are divided have an impact on the designation of the community's image if PGMI is part of the study program that will give birth to religious teacher candidates. This condition continues to be exacerbated by the existence of the PGMI curriculum system with the dominance of Islamic Religious Education (PAI) courses, writers often call it the "PAI flavored PGMI curriculum". The form of the curriculum at the beginning was clearly wrong because it did not match the achievement of competencies as an MI Class Teacher, namely mastery of pedagogical abilities and content in five MI subjects, Mathematics, Natural Sciences, Social Sciences, Civics, and Indonesian Language at MI level.

Second, curriculum changes were made in 2013. The direction of the curriculum changes at the PGMI Study Program at that time was focused on efforts to accommodate two policies that have been set, namely the policy on the Indonesian National Qualification Framework (KKNI), and the policy of implementing the 2013 curriculum. from the KBK (CompetencyBased Curriculum) to naming the Higher Education Curriculum has several important reasons, [9] including:

1. Naming the CBC is not entirely based on regulatory provisions, so it is still possible to continue to grow.

2. KBK bases its development on an agreement on the preparation of graduate competencies by representatives of study program organizers who will formulate the curriculum.

3. The absence of measurement parameters in the $\mathrm{CBC}$ system makes it difficult to judge whether one level of the study program is higher or lower than another.

4. The Indonesian National Qualification Framework (KKNI) provides measurement parameters in the form of qualification levels from the lowest level 1 to the highest level 9.

5. CP at each level of KKNI is described in the description of attitudes and values, abilities, knowledge, responsibilities and rights with a concise statement called generic descriptors.

6. K-DIKTI as a form of development of the KBK uses the KKNI qualification level as a measurement of $\mathrm{CP}$ as a curriculum compilation material for a study program. $\mathrm{g}$ ) The main 
difference between K-DIKTI and KBK is, therefore, the certainty of the level of study program because the $\mathrm{CP}$ obtained has a definite size.

Has the change in the curriculum of the PGMI study program considered the integration of Islam and Science? Some curriculum changes in the PGMI Study Program are still partial and have not been integrated with the vision of the university. The integration of Islam, scholarship, Indonesian-ness, modesty as echoed since 2002 is not very visible, especially regarding matters that are substantial. The pattern of integration is only seen only in the division of subjects between general science and Islamic science. For example, the 2007 curriculum as explained above there are a number of Islamic religion courses, such as AlQuran Hadith, Moral Tasawuf, Moral Aqeedah, Tafsir, Fiqh, Islamic Cultural History, Islamic Studies complete with their respective learning designs, so that in this decade's curriculum it's hard to distinguish between PGMI and PAI. But on the other hand, PGMI study programs offer a number of courses from the fields of language, science, social sciences, social studies, Civics, and Mathematics. It's just that the portion of the course has not met the competency needs of classroom teachers.

There is a slight difference in the 2011 curriculum, the portion of the curriculum has been adjusted to meet the needs as a classroom teacher. As a result, the curriculum offered has been directed at classroom teacher competencies, by combining several general subject groups (general subjects) and Islamic subject groups. There is a scientific group that is the target of achieving class teacher competency, namely 1 . Indonesian Language course groups, consisting of Indonesian Language and Literature Appreciators, Indonesian Skills Skills; 2) course groups, consisting of basic concepts of science, science learning, nutrition, and food, environmental education, Capita Selekta IPA; 3) Mathematics subject groups, consisting of Basic Mathematics, Geometry, Algebra, Opportunities and statistics, mathematics learning; 4) IPS / Civics courses group consists of Citizenship Education, basic concepts of Social Sciences, Social Studies / Civics Education, Indonesian History, World History, Pancasila, Nationalism, and globalization. There are a number of Islamic courses offered, including Fiqh, Elementary School Creed, Al-Quran Hadith, SKI, and PAI learning, the portion of credits for Islamic course groups is very small, only as a differentiator and differentiator with the Elementary Teacher Education Study Program.

Thus the pattern of conventional integration in the PGMI study program has actually been carried out, although it has not yet led to the actual implementation of integration. Policy Until now, the study program does not have the policy to connect one course to another, involving several different scientific lecturers. There is still no visible policy related to the student's obligation to write a thesis (including the submission of a title) by prioritizing patterns of scientific and Islamic integration. Policies that have been taken by study programs in the framework of implementing the integration of Islam and science are still very limited, namely: first, the circulation of study programs to all students and lecturers to conduct Al-Qur' an (especially the 30th juz) five minutes before lectures begin. Second, the circulation of study programs related to refraction dress like a teacher. All students are encouraged to always use polite clothing, good, according to the rules.

\section{References}

[1] Saud, Udin Syaefuddin: Inovasi Pendidikan. Bandung: Alpabeta. pp. 200 (2009).

[2] Nata, Abuddin dkk: Integrasi Keilmuan. Jakarta: RajaGrafindo Persada. Pp. 99 ( 2003). 
[3] Subandi, Al Marsudi: Pancasila dan UUD ' 45 dalam Paradigm Reformasi. Jakarta : PT. Raja Gravindo Persada. pp.78 (2006).

[4] https://www.webopedia.com/DidYouKnow/Internet/virus.asp

[5] Tilaar, H.A.R: Pendidikan, Kebudayaan, dan Masyarakat Madani. Bandung: Remaja Rosda Karya. Pp. 55 (1999).

[6] Tilaar, H.A.R: Pendidikan, Kebudayaan, dan Masyarakat Madani. Bandung: Remaja Rosda Karya. Pp. 57 (1999).

[7] Tilaar, H.A.R: Manajemen Pendidikan: Kajian Pendidikan Masa Depan. Bandung: Remaja Rosda Karya. Pp. 67. (1998).

[8] Guide to Higher Education Curriculum: 2014, pp. 12-13 (2014).

[9] Guide to Higher Education Curriculum: 2014, pp. 7 (2014). 